\title{
Динамика национального состава Азиатской России по материалам переписей (1926-1989 гг.)
}

М.А. СЕМЁНОВ, кандидат исторических наук, Институт истории СО РАН, Новосибирск. E-mail: pihterek@yandex.ru

В статье на основе данных всесоюзных переписей населения анализируется изменение национального состава Западной и Восточной Сибири, Дальнего Востока в период 1926-1989 гг. Раскрываются факторы, обусловливавшие эти изменения. Выяснено влияние основных исторических событий на этническую картину Азиатской России. Прослежены различия национального состава крупных экономико-географических регионов. Описаны особенности расселения основных этносов Сибири, включенности их в модернизационные процессы. Сделан вывод о ключевой роли процессов миграции и ассимиляции в формировании национальной структуры населения региона в этот период. Особое внимание уделено развитию автохтонных народов.

Ключевые слова: национальный состав, Западная Сибирь, Восточная Сибирь, Дальний Восток, миграции, ассимиляция, урбанизация

Этноэкономика в современных условиях приобретает все большую актуальность. Несмотря на оживленную дискуссию о содержании этого понятия, ее роли и месте в структуре экономической науки [Бредникова, Паченков, 2002; Овчинников, 2006; Киселева, 2007; Сурнина, 2009; Печура, 2010], значимой является тенденция введения в пространство экономики самого аспекта этнической принадлежности населения.

Этническая картина общества не остается неизменной и в ходе исторического развития претерпевает серьезные трансформации под влиянием процессов естественного воспроизводства населения, миграций, ассимиляции и т.д. Таким образом, изучение этнического состава общества, механизмов и степени влияния на него различных социальных, экономических, культурных процессов неизбежно должно основываться на прочном историческом фундаменте.

Важность изучения исторической динамики национального состава населения понимается исследователями, работающими в проблемном поле исторической демографии. Эта тема нашла свое освещение в ряде работ различного территориального 
и хронологического масштаба [Андреев и др., 1993; Население.., 1997; Бурматов, 1997; Этнодемографические.., 2003; Кузнецова, 2010; Миграции.., 2011; Дашинамжилов, Лыгденова, 2012; Жиромская, 2013; Сивцева, 2013; Дашинамжилов, Лыгденова, 2016a; Дашинамжилов, Лыгденова, 2016b]. Тем не менее потребность в анализе динамики национального состава крупных историко-географических регионов на протяжении длительных исторических периодов по-прежнему высока.

В рамках данной статьи проанализируем эволюцию национального состава такого крупного региона, как Сибирь ${ }^{1}$, в советский период ее истории. Выбор этих рамок не случаен. Во-первых, в XX в. произошел взрывной рост экономической роли Сибири в жизни страны. Во-вторых, в этот период она служит местом пересечения активных миграционных потоков, где встречались друг с другом и были вынуждены налаживать взаимодействие самые разные этносы.

Основным и наиболее точным источником сведений о национальном составе населения служат данные переписей.

Первая всеобщая перепись населения произошла в самом конце XIX века-в 1897 г. Вопрос о национальности в ней прямо не ставился. Его эквивалентом служил вопрос о родном языке опрашиваемого, что объясняется как недостаточно разработанными критериями национальной принадлежности, так и стремлением обойти острый для Российской империи национальный вопрос.

Следующей была советская перепись 1920 г., осуществлявшаяся в условиях продолжающейся Гражданской войны и становления новых органов государственной статистики. Все это определило крайне приблизительный характер ее сведений. По оценкам, она охватила всего $72 \%$ населения [Этнодемографические.., 2003. С. 4]. В 1923 г. была сделана еще одна попытка переписи населения, охватившая только городских жителей. Первой действительно всеобщей в советский период стала перепись 1926 г. Несмотря на все недостатки, ее проведение способствовало постановке дела переписей населения на прочную научную основу. Стало проводиться четкое различие между

Здесь и в дальнейшем Сибирь понимается в ее историко-географическом смысле все земли к востоку от Урала, вплоть до Тихого океана, ограниченные с юга Средней Азией и Китаем и включающие в себя три крупных экономико-географических района: Западную, Восточную Сибирь и Дальний Восток [Ядринцев, 2003. С. 6]. национальной принадлежностью опрашиваемого и его «религией, подданством, гражданством или признаком проживания в какойлибо республике» [Гозулов, 1936. С. 121].

После некоторых колебаний ${ }^{2}$ в основу определения понятия народности легла социально-психологическая точка зрения, согласно которой определение национальности базировалось на самосознании опрашиваемого, что позволяло эффективно учитывать влияние процессов ассимиляции и роста национального самосознания, потери и возвращения к своей народности [Гозулов, 1936. С. 122]. Данный подход сохранился неизменным при проведении переписей вплоть до нашего времени.

В 1930-е годы были проведены две переписи: в 1937 г. и 1939 г. Итоги переписи 1937 г. не удовлетворили высшее партийно-государственное руководство страны. Ее материалы остались закрыты от широкой общественности и вошли в научный оборот только в 1990 -е годы ${ }^{3}$. К сожалению, материалы переписи о национальном составе населения национальных областей и округов не сохранились [Этнодемографические.., 2003. С. 8], что затрудняет использование ее данных.

Перепись 1939 г., проводившуюся под пристальным контролем государства, зачастую обвиняют в преднамеренном завышении численности населения СССР. Однако, по мнению исследователей, углубленно изучавших эту проблему, размер приписок был незначителен, и ее данные вполне могут использоваться в качестве источника по демографической истории [Жиромская, 2001. С. 49; Этнодемографические.., 2003. С. 9].

После этого проведение переписей прекращается на достаточно долгий промежуток времени. Огромные демографические потери страны в годы Великой Отечественной войны, исчерпанность ее военно-мобилизационного потенциала в условиях холодной войны не могли стать достоянием широкой общественности.

\footnotetext{
Так, в переписи 1926 г. по сути смешивался социально-психологический и генетический (по родству) подходы к определению народности. Согласно инструкции предписывалось отмечать, «к какой народности причисляет себя опрашиваемый. В случаях, если отвечающий затрудняется ответить на вопрос, предпочтение отдается народности матери» [Гозулов, 1936. С. 121].

Всесоюзная перепись населения 1937 г.: Краткие итоги. М.: Институт истории СССР АН СССР. 1991. 239 с.; Всесоюзная перепись населения 1939 года. Основные итоги. М.: Наука. 1992. 256 с.
} 
Поэтому следующая перепись будет проведена лишь в 1959 г., когда потери военных лет компенсируются ростом населения.

После 1959 г. переписи в СССР становятся регулярными: они проводились в 1970, 1979, 1989 гг. При этом к 1950-м годам стабилизируется и административно-территориальное деление страны, претерпевавшее до этого постоянные изменения. Все это позволяет проводить сопоставление результатов переписей второй половины XX века и на уровне отдельных краев и областей.

\section{Структура национального состава Сибири по данным переписи 1926 г.}

Общая численность населения Сибири с 1897 г. по 1926 г., несмотря на неблагоприятное воздействие Первой мировой и Гражданской войн, выросла почти на две трети - с 5759 тыс. чел. до 9576 тыс. чел. Этому благоприятствовали воздействие активных миграционных процессов, в том числе в ходе Столыпинской аграрной реформы, а также высокая рождаемость. Всего за 1897-1914 гг. в Сибирь переселилось 2349 тыс. чел. [Миграции.., 2011. С. 23].

Национальный состав населения Сибири к 1926 г. имел следующий вид (табл. 1).

Ядро сибирского населения составляли русские (в целом по Сибири $-73,6 \%$ ). Значительными были украинская и белорусская диаспоры, резко увеличившиеся в результате миграционных процессов начала XX века. Если по переписи 1897 г. родным языком украинский назвали 233 тыс. сибиряков, а белорусский - 12 тыс., то, согласно переписи 1926 г., украинцев насчитывалось 1145 тыс. чел., а белорусов - 362 тыс. чел. Даже с учетом занижающего воздействия формулировки вопроса в переписи 1897 г. (не все украинцы и белорусы владели родным языком) рост численности этих народов выглядит впечатляюще. Их расселение по территории Сибири шло неравномерно. Если на территории Западной и Восточной Сибири украинцы в 1926 г. составляли 9,5\% населения, то на Дальнем Востоке - 18,2\%, т.е. там проживал каждый четвертый украинец. Характерно, что подобная диспропорция существовала и до массовых переселений начала XX века. По переписи 1897 г. доля считающих украинский язык родным составляла по Западной и Восточной Сибири в среднем $3,2 \%$, а на Дальнем Востоке $-8,9 \%$. Таким образом, несмотря на значительный абсолютный рост числа переселенцев, неравномерность расселения сохранялась. По всей видимости, наличие представителей своего этноса служило значимым фактором при выборе места поселения.

Таблица 1. Национальный состав Сибири по данным переписи 1926 r.

\begin{tabular}{|l|c|c|c|c|c|c|}
\hline \multirow{2}{*}{ Национальность } & \multicolumn{2}{|l}{ Городское население } & \multicolumn{2}{|c|}{ Сельское население } & \multicolumn{2}{|c|}{ Всего } \\
\cline { 2 - 7 } & чел. & $\%$ & чел. & $\%$ & чел. & $\%$ \\
\hline Русские & 1375483 & 85,52 & 6856276 & 71,60 & 8231759 & 73,60 \\
\hline Украинцы & 64931 & 4,04 & 1079928 & 11,28 & 1144859 & 10,24 \\
\hline Белорусы & 14075 & 0,88 & 347591 & 3,63 & 361666 & 3,23 \\
\hline Якуты & 5157 & 0,32 & 235405 & 2,46 & 240562 & 2,15 \\
\hline Буряты & 2306 & 0,14 & 235001 & 2,45 & 237307 & 2,12 \\
\hline Мордва & 6084 & 0,38 & 104537 & 1,09 & 110621 & 0,99 \\
\hline Татары & 33396 & 2,08 & 73575 & 0,77 & 106971 & 0,96 \\
\hline Корейцы & 8215 & 0,51 & 77662 & 0,81 & 85877 & 0,77 \\
\hline Немцы & 7993 & 0,50 & 73438 & 0,77 & 81431 & 0,73 \\
\hline Поляки & 18617 & 1,16 & 36801 & 0,38 & 55418 & 0,50 \\
\hline Чуваши & 1949 & 0,12 & 46567 & 0,49 & 48516 & 0,43 \\
\hline Казахи & 1059 & 0,07 & 47348 & 0,49 & 48407 & 0,43 \\
\hline Евреи & 39272 & 2,44 & 6354 & 0,07 & 45626 & 0,41 \\
\hline Хакасы & 476 & 0,03 & 45116 & 0,47 & 45592 & 0,41 \\
\hline Алтайцы & 93 & 0,01 & 38944 & 0,41 & 39037 & 0,35 \\
\hline Латыши & & & & & & \\
с латгальцами & 5862 & 0,36 & 31975 & 0,33 & 37837 & 0,34 \\
\hline Тунгусы & 98 & 0,01 & 37418 & 0,39 & 37516 & 0,34 \\
\hline Эстонцы & 2828 & 0,18 & 29280 & 0,31 & 32108 & 0,29 \\
\hline Шорцы & 70 & 0,00 & 12517 & 0,13 & 12587 & 0,11 \\
\hline Зыряне & 820 & 0,05 & 11732 & 0,12 & 12552 & 0,11 \\
\hline Чукчи & 8 & 0,00 & 12320 & 0,13 & 12328 & 0,11 \\
\hline Бухарцы & 545 & 0,03 & 11130 & 0,12 & 11675 & 0,10 \\
\hline $\begin{array}{l}\text { Прочие } \\
\text { национальности }\end{array}$ & 18952 & 1,18 & 124627 & 1,30 & 143579 & 1,28 \\
\hline Итого & 1608289 & 100,00 & 9575542 & 100,00 & 11183831 & 100,00 \\
\hline
\end{tabular}

Источники: URL: http://www.demoscope.ru со ссылкой на: Всесоюзная перепись населения 1926 года. М.: Издание цсу Союза ССР, 1928-1929. T. 9. C. $34-51$; T. 10. C. $9-13$; T. 11. C. $8-17$; T. 14. C. $6-16$; T. 15. C. $8-13$; Т. 16. С. 8-12; Т. 17. С. 8-25. Табл. VI. Население по полу, народности. Примечание к табл. 1-4: По территории Западной Сибири, Восточной Сибири, Дальнего Востока.

Другой крупной группой сибирского населения были автохтонные народы Сибири. К наиболее многочисленной группе относились якуты и буряты, составлявшие в 1926 г. 2,15 и $2,12 \%$ от общей численности населения соответственно. Для 
автохтонных народов было характерно проживание в пределах территории своего компактного расселения. Так, из 240562 якутов в пределах Якутской АССР проживали 235926 чел., а из 237367 бурятов в Бурят-Монгольской АССР - 214957. При этом в рамках данных административно-территориальных образований они занимали значительную долю в национальной структуре населения (якуты - 82,6\% жителей Якутской АССР, буряты - 43,9\% жителей Бурят-Монгольской АССР). Таким образом, компактность проживания позволяла этим народам достичь локального доминирования в национальном составе населения.

Определенную роль в формировании этнической картины Сибири играли народы Урала и Поволжья (мордва, чуваши, частично татары). Если в 1897 г. численность считающих татарский язык родным составляла 210 тыс. чел., то по переписи 1926 г. татар насчитывалось всего 107 тыс. чел. В то же время за этот период количество мордвы и чувашей резко возросло. Данный факт можно объяснить сочетанием двух различных по своей направленности процессов. С одной стороны, усилившейся миграцией из Поволжья в Сибирь в связи с голодом начала 1920-х годов. С другой - активной ассимиляцией сибирских татар, издавна проживавших в этом регионе. В целом совокупная доля народов Урала и Поволжья не превышала в 1920-е годы 3\% от общей численности населения Сибири.

Таким образом, несмотря на полиэтничность Сибири, доля неславянского этнического компонента не превышала 13\%. При этом в значительной мере его составляло автохтонное население, продолжавшее вести традиционный образ жизни и достаточно резко локализованное географически: на его долю в совокупности приходилось 5,6\% населения Сибири.

На долю пришлых неславянских этносов, не связанных границами традиционного расселения, приходилось около 7\% проживающих в Сибири. Самыми крупными из них были мордва (111 тыс. чел.), татары (107 тыс. чел.), корейцы (86 тыс. чел.), немцы (81 тыс. чел.).

Процесс урбанизации в 1920-е годы затрагивал в основном русское население, составлявшее около $86 \%$ горожан. При этом урбанизация в значительной мере была свойственна и национальным меньшинствам, затронутым ассимиляционными процессами: доля лиц, не знающих родного языка, среди представителей национальных меньшинств, проживающих в городе, была существенно выше. Значительной была среди них и гендерная диспропорция: в основном горожанами становились мужчины, прибывавшие туда в поисках работы. Исключение составляла еврейская диаспора, почти полностью сосредоточенная в городах.

\section{Этническая картина Сибири в 1930-е годы}

Гигантские стройки пятилеток, создание новой промышленной базы на востоке страны обусловили значительные масштабы миграции. Только в Западную и Восточную Сибирь в 1933-1937 гг. прибыло 880,7 тыс. чел. из других районов страны (за вычетом прибывших с Дальнего Востока) (Рассчитано по: [Московский, 1968. С. 70]). Вкупе с высоким естественным приростом это обусловило дальнейший рост удельного веса русского населения в Сибири с 73,6\% в 1926 г. до 82,3\% в 1939 г. При этом удельный вес русского населения в городах был еще выше - 86,75\%. Как и ранее, доля русского населения снижалась при движении с запада на восток. Максимальной она была в Западной Сибири $(85,4 \%)$, чуть меньше - в Восточной (84,2\%), на Дальнем Востоке - 69,1\%.

Серьезные изменения произошли в межпереписной период с населявшими Сибирь украинцами и белорусами. Численность украинцев снизилась на 13\% - с 1145 тыс. чел. в 1926 г. до 995 тыс. чел. в 1939 г., а белорусов - на 60\%, с 362 тыс. чел. до 146 тыс. чел. Причинами столь серьезного сокращения стали, наряду с возвращением в родную республику, миграцией в другие регионы, ассимиляционные процессы, которые облегчали культурная близость, схожесть хозяйственной деятельности с доминирующим русским населением. Косвенное подтверждение этот факт находит в различных темпах снижения численности украинцев в разных регионах. Так, на Дальнем Востоке, где существовала большая украинская диаспора, абсолютная численность украинцев осталась фактически на прежнем уровне. Падение их удельного веса в национальном составе объясняется общим ростом численности населения Дальнего Востока. То есть показатели ассимиляции не превышали уровень естественного прироста украинского населения. В то же время на остальной территории Сибири, где относительное количество украинцев было меньше и не позволяло создавать крупные этнические 
анклавы, происходит значительное как абсолютное, так и относительное уменьшение их численности.

В этот период значительно выросла миграция тюркских и угро-финских народов с Урала и Поволжья - численность татар к концу 1930-х годов возрастает по сравнению с 1926 г. более чем в 2,5 раза, чувашей - почти в два раза, мордвы - в 1,5 раза.

При этом их численность, так же как и у русских, падает по мере удаления от мест исторического проживания: максимальное их количество проживало в Западной Сибири, минимальное - на Дальнем Востоке.

Резко возрастает в этот период в Сибири численность казахов. Если в 1926 г. их насчитывалось чуть больше 48 тыс. чел., то спустя 13 лет казахская диаспора составляла 110 тыс. чел. Основным местом их проживания были пограничные с Казахской ССР Омская область и Алтайский край, в которых насчитывалось более 79 тыс. казахов.

Другим этносом, чья численность резко выросла за этот период, были евреи. С 1928 г. начинается активная деятельность Ком3ЕТа ${ }^{4}$ по переселению евреев в Приамурье, а в 1934 г. образована Еврейская автономная область. Создание первого в мире национального административно-территориального образования евреев привело к тому, что их количество в Сибири выросло с 46 тыс. чел. в 1926 г. до почти 83 тыс. чел. в 1939 г. При этом на территории Хабаровского края, в состав которого входила Еврейская автономная область, проживали 31 тыс. евреев.

Автохтонные сибирские народы демонстрируют в это время достаточно медленное увеличение своей численности, отстающее от средних темпов роста населения Сибири, либо даже некоторое его сокращение (буряты, алтайцы). Это приводит к снижению относительной доли этих народов: самый многочисленный из них - якуты - составляют всего $1,45 \%$ сибирского населения, буряты $-1,31 \%$, хакасы $-0,31 \%$, алтайцы - 0,27\%, шорцы $-0,09 \%$. При этом сохраняется компактность их расселения. Так, из почти 250 тыс. якутов за пределами собственно Якутской АССР проживали всего 8144 чел. Из 13814 чукчей на территории Западной Сибири проживал всего один, а в Восточной Сибири - четверо. Из

\footnotetext{
${ }^{4}$ Комитет по земельному устройству еврейских трудящихся при Президиуме Совета национальностей ЦИК СССР.
}

18396 хантов в Восточной Сибири жили всего семеро, а на Дальнем Востоке - 12 .

В то же время повышается вовлеченность ряда народов в процессы урбанизации - резко возрастает доля городского населения среди украинцев, белорусов, татар, мордвы. Хотя абсолютное количество горожан среди автохтонных народов по-прежнему было невелико, происходит значительный относительный рост числа проживающих в городе бурятов, якутов, алтайцев, хакасов, различных народностей Севера.

В целом национальный состав Сибири в конце 1930-х годов характеризуют данные таблицы 2.

Таблица 2. Национальный состав Сибири по данным переписи 1939 r.

\begin{tabular}{|l|c|c|c|c|c|c|}
\hline \multirow{2}{*}{$\begin{array}{c}\text { Националь- } \\
\text { ность }\end{array}$} & \multicolumn{2}{|c|}{ Городское население } & \multicolumn{2}{c|}{ Сельское население } & \multicolumn{2}{c|}{ Всего } \\
\cline { 2 - 7 } & чел. & $\%$ & чел. & $\%$ & чел. & $\%$ \\
\hline Русские & 4943268 & 86,75 & 8780666 & 79,99 & 13723934 & 82,30 \\
\hline Украинцы & 294517 & 5,17 & 700960 & 6,39 & 995477 & 5,97 \\
\hline Татары & 99330 & 1,74 & 178312 & 1,62 & 277642 & 1,66 \\
\hline Якуты & 16444 & 0,29 & 224973 & 2,05 & 241417 & 1,45 \\
\hline Буряты & 19161 & 0,34 & 198742 & 1,81 & 217903 & 1,31 \\
\hline Мордва & 63041 & 1,11 & 108224 & 0,99 & 171265 & 1,03 \\
\hline Белорусы & 42462 & 0,75 & 103305 & 0,94 & 145767 & 0,87 \\
\hline Немцы & 15169 & 0,27 & 101844 & 0,93 & 117013 & 0,70 \\
\hline Казахи & 19561 & 0,34 & 90709 & 0,83 & 110270 & 0,66 \\
\hline Чуваши & 20351 & 0,36 & 67749 & 0,62 & 88100 & 0,53 \\
\hline Евреи & 64444 & 1,13 & 18420 & 0,17 & 82864 & 0,50 \\
\hline Хакасы & 6319 & 0,11 & 44875 & 0,41 & 51194 & 0,31 \\
\hline Ойроты & 3759 & 0,07 & 41704 & 0,38 & 45463 & 0,27 \\
\hline Поляки & 20325 & 0,36 & 25063 & 0,23 & 45388 & 0,27 \\
\hline Латыши & 9542 & 0,17 & 27116 & 0,25 & 36658 & 0,22 \\
\hline с латгальцами & 6432 & 0,11 & 27145 & 0,25 & 33577 & 0,20 \\
\hline Эстонцы & 1512 & 0,03 & 27945 & 0,25 & 29457 & 0,18 \\
\hline Эвенки & 5062 & 0,09 & 23253 & 0,21 & 28315 & 0,17 \\
\hline Коми & 3795 & 0,07 & 14828 & 0,14 & 18623 & 0,11 \\
\hline Удмурты & 525 & 0,01 & 17871 & 0,16 & 18396 & 0,11 \\
\hline Ханты & 372 & 0,01 & 16773 & 0,15 & 17145 & 0,10 \\
\hline Ненцы & 7147 & 0,13 & 9961 & 0,09 & 17108 & 0,10 \\
\hline Китайцы & 1726 & 0,03 & 14070 & 0,13 & 15796 & 0,09 \\
\hline Шорцы & 0,00 & 13669 & 0,12 & 13814 & 0,08 \\
\hline Чукчи & & & & & & \\
\hline
\end{tabular}




\begin{tabular}{|l|c|c|c|c|c|c|}
\hline \multirow{2}{*}{$\begin{array}{c}\text { Националь- } \\
\text { ность }\end{array}$} & \multicolumn{2}{|c|}{ Городское население } & \multicolumn{2}{c|}{ Сельское население } & \multicolumn{2}{c|}{ Окончание табл. 2} \\
\cline { 2 - 7 } & чел. & $\%$ & чел. & $\%$ & чел. & $\%$ \\
\hline $\begin{array}{l}\text { Прочие } \\
\text { национальности }\end{array}$ & 33819 & 0,59 & 99455 & 0,91 & 133274 & 0,80 \\
\hline Всего & 5698228 & 100,00 & 10977632 & 100,00 & 16675860 & 100,00 \\
\hline
\end{tabular}

Источник: URL: http://www.demoscope.ru со ссылкой на: РГАЭ. Ф. 1562. Оп. 336. Ед.хр. 966-1001.

\section{После тяжелых испытаний: национальный состав Сибири в 1959 г.}

Национальный состав населения Сибири по данным переписи 1959 г. выглядел следующим образом (табл. 3).

Таблица 3. Национальный состав населения Сибири по данным переписи 1959 г.

\begin{tabular}{|l|c|c|c|c|c|c|c|c|}
\hline \multirow{2}{*}{$\begin{array}{c}\text { Националь- } \\
\text { ность }\end{array}$} & \multicolumn{2}{|c|}{ Западная Сибирь } & \multicolumn{2}{|c|}{$\begin{array}{c}\text { Восточная } \\
\text { Сибирь }\end{array}$} & \multicolumn{2}{|c|}{ Дальний Восток } & \multicolumn{2}{|c|}{ Всего по Сибири } \\
\cline { 2 - 10 } & чел. & $\%$ & чел. & $\%$ & чел. & $\%$ & чел. & $\%$ \\
\hline Русские & 9556899 & 84,94 & 5378912 & 83,10 & 3745957 & 77,49 & 18681768 & 82,81 \\
\hline Украинцы & 449609 & 4,00 & 216957 & 3,35 & 441531 & 9,13 & 1108097 & 4,91 \\
\hline Немцы & 437938 & 3,89 & 77571 & 1,20 & 11253 & 0,23 & 526762 & 2,34 \\
\hline Буряты & 312 & 0,00 & 246546 & 3,81 & 1220 & 0,03 & 248078 & 1,10 \\
\hline Якуты & 140 & 0,00 & 6076 & 0,09 & 228145 & 4,72 & 234361 & 1,04 \\
\hline $\begin{array}{l}\text { Татары, В т.ч. } \\
\text { крымские }\end{array}$ & 223627 & 1,99 & 99697 & 1,54 & 58933 & 1,22 & 382257 & 1,69 \\
\hline Белорусы & 75036 & 0,67 & 53473 & 0,83 & 59189 & 1,22 & 187698 & 0,83 \\
\hline Мордва & 58654 & 0,52 & 29701 & 0,46 & 49336 & 1,02 & 137691 & 0,61 \\
\hline $\begin{array}{l}\text { Народности } \\
\text { Севера }\end{array}$ & 43040 & 0,38 & 13331 & 0,21 & 60139 & 1,24 & 116510 & 0,52 \\
\hline В том числе: & & & & & & & & \\
ненцы & 14828 & 0,13 & 1925 & 0,03 & 0 & 0,00 & 16753 & 0,07 \\
\hline ханты & 18703 & 0,17 & 0 & 0,00 & 0 & 0,00 & 18703 & 0,08 \\
\hline чукчи & 0 & 0,00 & 0 & 0,00 & 11499 & 0,24 & 11499 & 0,05 \\
\hline эвенки & 307 & 0,00 & 8956 & 0,14 & 14996 & 0,31 & 24259 & 0,11 \\
\hline Чуваши & 66152 & 0,59 & 34340 & 0,53 & 14644 & 0,30 & 115136 & 0,51 \\
\hline Тувинцы & 0 & 0,00 & 99040 & 1,53 & 0 & 0,00 & 99040 & 0,44 \\
\hline Евреи & 38352 & 0,34 & 22268 & 0,34 & 36337 & 0,75 & 96957 & 0,43 \\
\hline Казахи & 88015 & 0,78 & 3732 & 0,06 & 4005 & 0,08 & 95752 & 0,42 \\
\hline Корейцы & 1748 & 0,02 & 2257 & 0,03 & 68140 & 1,41 & 72145 & 0,32 \\
\hline Хакасы & 927 & 0,01 & 53542 & 0,83 & 0 & 0,00 & 54469 & 0,24 \\
\hline Литовцы & 9226 & 0,08 & 34834 & 0,54 & 3684 & 0,08 & 47744 & 0,21 \\
\hline Алтайцы & 43685 & 0,39 & 25 & 0,00 & 0 & 0,00 & 43710 & 0,19 \\
\hline
\end{tabular}

\begin{tabular}{|l|c|c|c|c|c|c|c|c|}
\hline \multirow{2}{*}{$\begin{array}{l}\text { Националь- } \\
\text { ность }\end{array}$} & Западная Сибирь & \multicolumn{2}{|c|}{$\begin{array}{c}\text { Восточная } \\
\text { Сибирь }\end{array}$} & \multicolumn{2}{|c|}{ Дальний Восток } & \multicolumn{2}{|c|}{ Всего по Сибири } \\
\cline { 2 - 10 } & чел. & $\%$ & чел. & $\%$ & чел. & $\%$ & чел. & $\%$ \\
\hline Латыши & 16913 & 0,15 & 14396 & 0,22 & 3819 & 0,08 & 35128 & 0,16 \\
\hline Поляки & 16101 & 0,14 & 11570 & 0,18 & 7220 & 0,15 & 34891 & 0,15 \\
\hline Эстонцы & 16564 & 0,15 & 12469 & 0,19 & 2518 & 0,05 & 31551 & 0,14 \\
\hline Удмурты & 8613 & 0,08 & 6800 & 0,11 & 4051 & 0,08 & 19464 & 0,09 \\
\hline $\begin{array}{l}\text { Коми и коми- } \\
\text { пермяки }\end{array}$ & 16793 & 0,15 & 1618 & 0,02 & 442 & 0,01 & 18853 & 0,08 \\
\hline Молдаване & 9874 & 0,09 & 3397 & 0,05 & 4714 & 0,10 & 17985 & 0,08 \\
\hline Башкиры & 6441 & 0,06 & 4289 & 0,07 & 3644 & 0,08 & 14374 & 0,06 \\
\hline Шорцы & 13946 & 0,12 & 0 & 0,00 & 0 & 0,00 & 13946 & 0,06 \\
\hline Калмыки & 7685 & 0,07 & 4160 & 0,06 & 0 & 0,00 & 11845 & 0,05 \\
\hline Армяне & 4949 & 0,04 & 3131 & 0,05 & 3089 & 0,06 & 11169 & 0,05 \\
\hline Цыгане & 6178 & 0,05 & 3757 & 0,06 & 780 & 0,02 & 10715 & 0,05 \\
\hline $\begin{array}{l}\text { Прочие } \\
\text { националь- } \\
\text { ности }\end{array}$ & 34146 & 0,30 & 35303 & 0,55 & 21356 & 0,44 & 90805 & 0,40 \\
\hline Всего & 11251563 & 100,00 & 6473192 & 100,00 & 4834146 & 100,00 & 22558901 & 100,00 \\
\hline
\end{tabular}

Источник: URL: http://www.demoscope.ru со ссылкой на: РГАЭ. Ф. 1562. Оп. 336. Ед.хр. $1566 \mathrm{a}-1566$ д.

Основу сибирского населения составляли русские. По сравнению с данными переписи 1939 г. их удельный вес в составе населения Сибири остался фактически неизменным. При этом в Западной и Восточной Сибири удельный вес русских снизился, что было вызвано большими потерями в ходе Великой Отечественной войны, миграциями, а также резким ростом числа таких национальностей, как немцы и тувинцы. В то же время на Дальнем Востоке доля русского населения выросла на 8\%, в первую очередь за счет миграционного прироста.

В 1944 г. в состав СССР вошла Тувинская Народная Республика, ставшая Тувинской автономной областью в составе РСФСР. Тувинцы по сибирским меркам были достаточно крупным народом (к 1959 г. - около 100 тыс. чел).

Следует отметить, что после ликвидации АССР немцев Поволжья и их депортации в восточные районы страны немецкое население стало одной из наиболее многочисленных групп сибирского населения (527 тыс. чел., около 3\% от общей численности), уступая лишь русским и украинцам.

Удельный вес коренных народов Сибири не превышал в Западной Сибири 0,9\% населения (наиболее многочисленными из них 
были алтайцы - 43 тыс. чел., ханты - 19 тыс. чел., ненцы - 15 тыс. чел., шорцы - 14 тыс. чел.), в Восточной - 6,4\% (буряты - 247 тыс. чел., тувинцы - 99 тыс. чел., хакасы - 53,5 тыс. чел.), на Дальнем Востоке - 6\% (якуты - 228 тыс. чел, эвенки - 15 тыс. чел., чукчи - 11,5 тыс. чел). Для коренных народов по-прежнему было характерно компактное проживание, преимущественно в сельской местности. Стоит отметить, что в этот период буряты, тувинцы, хакасы демонстрируют устойчивое увеличение численности. Так, число бурятов за прошедшие с переписи 1939 г. двадцать лет увеличилось на 30 тыс., хакасов - на 5 тыс. чел. В то время как численность алтайцев, шорцев, ряда народностей Севера продолжала сокращаться.

\section{Изменения национального состава Сибири \\ в 1970-1989 гr.}

В 1970-1980-е гг. основу сибирского населения по-прежнему составляли русские. По данным переписи 1979 г. их абсолютная численность и удельный вес в национальном составе региона достигают максимума. Но перепись 1989 г. зафиксировала тенденцию к сокращению удельного веса русского населения, что было вызвано целым рядом факторов: активной миграцией в регион представителей других национальностей, относительно низким показателем естественного прироста у русского населения, негативным влиянием развернувшихся в стране общественно-политических процессов. В этот период впервые за долгое время происходит существенный прирост числа украинцев и белорусов (табл. 4).

Начинается бурный рост численности коренных народов Восточной Сибири: в частности, бурятов, якутов и тувинцев на треть. Больше становится и представителей малочисленных народностей Севера. Численность и удельный вес ряда народов Урала и Поволжья - мордвы и чувашей - остаются стабильными или снижаются.

Значимую часть сибирского населения составляли жители пограничной Казахской ССР, где к 1989 г. проживало более 151 тыс. чел.

Новым явлением в динамике национального состава Сибири стало формирование достаточно крупных диаспор выходцев из республик Закавказья и Средней Азии.
Таблица 4. Изменение национального состава населения Сибири по данным переписей 1970, 1979, 1989 гг., чел.

\begin{tabular}{|l|c|c|c|c|c|c|}
\hline \multirow{2}{*}{$\begin{array}{c}\text { Националь- } \\
\text { ность }\end{array}$} & \multicolumn{2}{|c|}{1970} & \multicolumn{2}{c|}{$\mathbf{1 9 7 9}$} & \multicolumn{2}{c|}{$\mathbf{1 9 8 9}$} \\
\cline { 2 - 7 } & чел. & \% & чел. & \% & чел. & $\%$ \\
\hline Русские & 21470653 & 84,69 & 23704065 & 84,74 & 26747740 & 83,29 \\
\hline Украинцы & 943454 & 3,72 & 1107192 & 3,96 & 1483846 & 4,62 \\
\hline Татары & 447852 & 1,77 & 495737 & 1,77 & 605139 & 1,88 \\
\hline Немцы & 471774 & 1,86 & 475570 & 1,70 & 502283 & 1,56 \\
\hline Буряты & 309859 & 1,22 & 345842 & 1,24 & 411090 & 1,28 \\
\hline Якуты & 292971 & 1,16 & 323362 & 1,16 & 375977 & 1,17 \\
\hline Белорусы & 193830 & 0,76 & 217507 & 0,78 & 287322 & 0,89 \\
\hline Тувинцы & 138042 & 0,54 & 164588 & 0,59 & 204108 & 0,64 \\
\hline Казахи & 107051 & 0,42 & 117685 & 0,42 & 151188 & 0,47 \\
\hline Чуваши & 133629 & 0,53 & 130297 & 0,47 & 143639 & 0,45 \\
\hline Мордва & 112552 & 0,44 & 99919 & 0,36 & 99707 & 0,31 \\
\hline Башкиры & 19718 & 0,08 & 34639 & 0,12 & 80313 & 0,25 \\
\hline Хакасы & 64076 & 0,25 & 68137 & 0,24 & 75888 & 0,24 \\
\hline Азербайджанцы & 6882 & 0,03 & 18165 & 0,06 & 72033 & 0,22 \\
\hline Алтайцы & 54081 & 0,21 & 58238 & 0,21 & 68405 & 0,21 \\
\hline Корейцы & 72745 & 0,29 & 61984 & 0,22 & 64305 & 0,20 \\
\hline Молдаване & 15140 & 0,06 & 24508 & 0,09 & 57124 & 0,18 \\
\hline Евреи & 78358 & 0,31 & 66054 & 0,24 & 54792 & 0,17 \\
\hline Узбеки & 11728 & 0,05 & 19533 & 0,07 & 39279 & 0,12 \\
\hline Армяне & 10999 & 0,04 & 18875 & 0,07 & 37893 & 0,12 \\
\hline Удмурты & 28756 & 0,11 & 30412 & 0,11 & 34227 & 0,11 \\
\hline Марийцы & 22201 & 0,09 & 24895 & 0,09 & 34002 & 0,11 \\
\hline Эвенки & 24832 & 0,10 & 25879 & 0,09 & 29394 & 0,09 \\
\hline Поляки & 28579 & 0,11 & 28481 & 0,10 & 28752 & 0,09 \\
\hline Ненцы & 21310 & 0,08 & 21744 & 0,08 & 25592 & 0,08 \\
\hline Ханты & 20710 & 0,08 & 20134 & 0,07 & 21540 & 0,07 \\
\hline Грузины & 7467 & 0,03 & 12738 & 0,05 & 19911 & 0,06 \\
\hline Эстонцы & 24840 & 0,10 & 21869 & 0,08 & 19421 & 0,06 \\
\hline Латыши & 24005 & 0,09 & 24896 & 0,09 & 19115 & 0,06 \\
\hline Цыгане & 11900 & 0,05 & 14113 & 0,05 & 17608 & 0,05 \\
\hline Литовцы & 18532 & 0,07 & 15552 & 0,06 & 17219 & 0,05 \\
\hline Эвены & 11738 & 0,05 & 12296 & 0,04 & 16772 & 0,05 \\
\hline Коми & 16600 & 0,07 & 15892 & 0,06 & 15999 & 0,05 \\
\hline Шорцы & 15759 & 0,06 & 14888 & 0,05 & 15314 & 0,05 \\
\hline Чукчи & 13364 & 0,05 & 13822 & 0,05 & 14929 & 0,05 \\
\hline Осетины & 5555 & 0,02 & 8731 & 0,03 & 13876 & 0,04 \\
\hline
\end{tabular}




\begin{tabular}{|l|c|c|c|c|c|c|}
\hline \multirow{2}{*}{$\begin{array}{c}\text { Националь- } \\
\text { ность }\end{array}$} & \multicolumn{2}{|c|}{1970} & \multicolumn{2}{c|}{1979} & \multicolumn{2}{c|}{ Окончание табл. 4 } \\
\cline { 2 - 7 } & чел. & $\%$ & чел. & $\%$ & чел. & $\%$ \\
\hline Киргизы & 2960 & 0,01 & 3415 & 0,01 & 13679 & 0,04 \\
\hline Чеченцы & 1775 & 0,01 & 3948 & 0,01 & 13040 & 0,04 \\
\hline Нанайцы & 9778 & 0,04 & 10126 & 0,04 & 11583 & 0,04 \\
\hline Таджики & 2095 & 0,01 & 4166 & 0,01 & 10030 & 0,03 \\
\hline $\begin{array}{l}\text { Прочие } \\
\text { национальности }\end{array}$ & 85294 & 0,34 & 94199 & 0,34 & 161623 & 0,50 \\
\hline Всего & 25353444 & 100,00 & 27974093 & 100,00 & 32115697 & 100,00 \\
\hline
\end{tabular}

Источник: URL: http://www.demoscope.ru со ссылкой на: РГАЭ/ Ф. 1562. Оп. 69. Д.204-232; Оп. 336. Д. 3998-4185, 6181-6208.

Как и раньше, среди городского населения удельный вес русских был выше, чем в среднем по Сибири, достигая 88,8\% в 1970 г. и 85,9\% - в 1989 г. Преимущественно городской образ жизни вели также украинцы, татары, белорусы. Заметным явлением становится все большая вовлеченность в процесс урбанизации коренных народов. Число тувинцев-горожан выросло за указанный период втрое, бурятов - более чем в два раза.

На селе русское население продолжало убывать, как в абсолютном, так и в относительном отношении: к 1989 г. они составляли 76\% сельского населения. Численность большинства других национальностей на селе оставалась стабильной или снижалась. Существенный рост сельского населения был характерен лишь для якутов, тувинцев и алтайцев.

\section{Заключение}

Народы, населяющие Сибирь, можно условно разделить на две большие группы: автохтонные и пришлые, что в значительной степени определяет особенности их развития.

Для автохтонных народов характерны увеличение численности исключительно за счет естественного прироста, компактное расселение, локальное доминирование в национальной структуре, крайне слабое участие в урбанизационных и миграционных процессах.

Численность пришлых народов в значительной мере зависит от миграционных процессов. Для них характерны дисперсное расселение, сокращение численности по мере удаления от территории исторического расселения, активное участие в процессе урбанизации.
При этом соотношение различных этносов было крайне неравномерным: пришлых народов было в разы больше, чем автохтонных. Доминирующее положение среди пришлых народов занимали русские, что в целом определяло этническую картину Сибири.

При этом русские наиболее активно среди сибирских этносов участвовали в модернизационных процессах. Городское население Сибири изначально складывалось как прежде всего русское. Новый тип городского жителя, новые формы экономической занятости начинают ассоциироваться с русской идентичностью. Таким образом, компактность проживания, сравнительная однородность хозяйственной деятельности горожан вкупе с заметным культурным доминированием русских становятся факторами, резко усиливающими ассимиляционные процессы.

Ассимиляция с доминирующим этносом становится обратной стороной урбанизации. Остальные этносы оказываются перед нелегким историческим выбором: либо свести к минимуму свое участие в модернизационных процессах ради сохранения этнической идентичности, замкнуться в границах своего исторического расселения, либо встроиться в процессы модернизации и подвергнуться мощному ассимиляционному воздействию.

\section{Литература}

Андреев Е.М., Дарский Л.Е., Харькова Т.Л. Население Советского Союза: 1922-1991. М.: Наука, 1993. 143 с.

Бредникова О.Е., Паченков О.В. Этничность «этнической экономики» и социальные сети мигрантов // Экономическая социология. 2002. № 2. С. 74-81.

Бурматов А.А. Демографическая история Каинска-Куйбышева и его округи. Новосибирск: Изд-во НГПУ. 1997. 162 с.

Гозулов А.И. Переписи населения СССР и капиталистических стран (опыт историко-методологической характеристики производства переписей населения). М.: Ред.-изд. Упр-е ЦУНХУ Госплана СССР и В/О «Союзоргучет», 1936. 588 с.

Дашинамжилов О.Б., Лыгденова В. В. Динамика изменения этнического состава населения Сибири в 1989-2010 гг. // Социс. 2012. № 10. С. 50-54.

Дашинамжилов О.Б., Лыгденова В.В. Национальный состав населения Западной Сибири в 1959-1989 гг. // Гуманитарные науки в Сибири. 2016а. № 3. T. 23. С. $113-116$.

Дашинамжилов О.Б., Лыгденова В.В. Этнодемографические процессы в Западной Сибири в постсоветский период (1989-2010 гг.) // Вестник Томского государственного университета. 2016b. № 6 (44). С. 143-150.

Жиромская В.Б. Демографическая история России в 1930-е годы: взгляд в неизвестное. М.: РОССПЭН, 2001. 280 с.

Жиромская В.Б. Основные тенденции демографического развития России в XX веке. М.: Кучково поле, 2013. 320 с. 
Киселева H. H. Этноэкономическая составляющая системной организации Юга России // Успехи современного естествознания. 2007. № 11. С. 91-93.

Кузнецова Я.А. Проблемы демографического развития Республики Бурятии в 1970-1980 гг. // Проблемы исторической демографии Сибири. Вып. 1. Новосибирск: Ин-т истории СО РАН, 2010. С. 223-241.

Миграции населения Азиатской России: конец XIX - начало XXI вв. / Отв. ред. В. А. Исупов. Новосибирск: Параллель, 2011. 392 с.

Московский А. С. Формирование и развитие рабочего класса Сибири в период строительства социализма. Новосибирск: Наука, 1968. 308 с.

Население Западной Сибири в XX веке / Отв.ред. Н. Я. Гущин, В. А. Исупов. Новосибирск: Изд-во СО РАН, 1997. 172 с.

Овчинников В. Н. Этноэкономика как фактор развития // Проблемы прогнозирования. 2006. № 1. С. 118-123.

Печура О.В. Этноэкономика региона: теоретико-методологический аспект // Вестник Челябинского государственного университета. 2010. № 3. С. 56-60.

Сивцева С.И. Население Якутии в XX веке: некоторые аспекты формирования // Проблемы исторической демографии Сибири. Вып. 3. Новосибирск: Ин-т истории СО РАН, 2013. С. 55-67.

Сурнина Н.М. Этноэкономическая парадигма в контексте теории диалога цивилизаций // Вестник Томского государственного университета. 2009. № 4. С. 5-12.

Этнодемографические взаимодействия народов Сибири. Историко-статистические документы. Отв. ред. В. А. Исупов. Новосибирск: НГУ, 2003. 138 с.

Ядринцев Н.М. Сибирь как колония в географическом, этнографическом и историческом отношении/ Под ред. Н.Н. Покровского. Новосибирск: Ин-т истории СО РАН, 2003. 556 с.

Статья поступила 09.04.2018.

\section{Summary}

Semenov M. A., Institute of History, SB RAS, Novosibirsk

Dynamics of Ethnic Composition of the Asian Part of Russia According to the Census (1926-1989)

The article analyzes the changes in the national composition of Western and Eastern Siberia and the Far East in the period 1926-1989 on the basis of the data of all-Union population censuses. The influence of the main historical events on the ethnic picture of Asian Russia is revealed. Differences in the national composition of large economic and geographical regions are traced. Features of settling of the main ethnic groups of Siberia, their inclusion in modernization processes are described. The conclusion about the key role of migration and assimilation processes in the formation of the nationa structure of the population of the region in this period is made. Special attention is paid to the development of autochthonous peoples.

National composition; Western Siberia; Eastern Siberia; Far East; migrations, assimilation; urbanization

\section{References}

Andreev E. M., Darskij L.E., Har'kova T.L. (1993) Naselenie Sovetskogo Soyuza: 1922-1991. Moscow, Nauka Publ. 143 p. (In Russ.)

Brednikova O.E., Pachenkov O.V. (2002) Etnichnost' «ehtnicheskoj ehkonomiki» i social'nye seti migrantov. Ekonomicheskaya sociologiya [Economic Sociology]. No. 2. Pp. 74-81. (In Russ.)
Burmatov A.A. (1997) Demograficheskaya istoriya Kainska-Kujbysheva i ego okrugi. Novosibirsk, NGPU Publ. 162 p. (In Russ.)

Gozulov A.I. (1936) Perepisi naseleniya SSSR i kapitalisticheskih stran (opyt istoriko-metodologicheskoj harakteristiki proizvodstva perepisej naseleniya). Moscow, Upravlenie CUNHU Gosplana SSSR i V/O «Soyuzorguchet» Publ. 588 p. (In Russ.)

Dashinamzhilov O. B., Lygdenova V.V. (2012) Dinamika izmeneniya ehtnicheskogo sostava naseleniya Sibiri v 1989-2010 gg. Sotsiologicheskie Issledovaniia [Sociological Studies]. No. 10. Pp. 50-54. (In Russ.)

Dashinamzhilov O.B., Lygdenova V.V. (2016a) Nacional'nyj sostav naseleniya Zapadnoj Sibiri v 1959-1989 gg. Gumanitarnye nauki v Sibiri. [Humanitarian sciences in Siberia]. No. 3. T. 23. Pp. 113-116. (In Russ.)

Dashinamzhilov O.B., Lygdenova V.V. (2016b) Etnodemograficheskie processy v Zapadnoj Sibiri v postsovetskij period (1989-2010 gg.). Vestnik Tomskogo gosudarstvennogo universiteta [Tomsk State Pedagogical University Bulletin]. No. 6 (44). Pp. 143-150. (In Russ.)

Zhiromskaya V.B. (2001) Demograficheskaya istoriya Rossii v 1930-e gody: vzglyad v neizvestnoe. Moscow, ROSSPEHN Publ. 280 p. (In Russ.)

Zhiromskaya V.B. (2013) Osnovnye tendencii demograficheskogo razvitiya Rossii v XX veke. Moscow, Kuchkovo pole Publ. 320 p. (In Russ.)

Kiseleva N.N. (2007) Etnoehkonomicheskaya sostavlyayushchaya sistemnoj organizacii Yuga Rossii. Uspekhi sovremennogo estestvoznaniya [Advances in current natural sciences]. No. 11. Pp. 91-93. (In Russ.)

Kuznecova Ya.A.(2010) Problemy demograficheskogo razvitiya Respubliki Buryatii v 1970-1980 gg. In: Problemy istoricheskoj demografii Sibiri. Vyp. 1. [Problems of historical demography of Siberia. Vol. 1.]. Novosibirsk, Institut istorii SO RAN Publ. Pp.223-241. (In Russ.)

Migracii naseleniya Aziatskoj Rossii: konec XIX - nachalo XXI vv. (2011) Novosibirsk, Parallel' Publ. 392 p. (In Russ.)

Moskovskij A. S. (1968) Formirovanie i razvitie rabochego klassa Sibiri v period stroitel'stva socializma. Novosibirsk, Nauka Publ. 308 p. (In Russ.)

Naselenie Zapadnoj Sibiri v XX veke. (1997) Novosibirsk, SO RAN Publ. 172 p. (In Russ.)

Ovchinnikov V.N. (2006) Etnoehkonomika kak faktor razvitiya. Problemy prognozirovaniya [Studies on Russian Economic Development]. No. 1. Pp. 118-123. (In Russ.)

Pechura O.V. (2010) Etnoehkonomika regiona: teoretiko-metodologicheskij aspect. Vestnik Chelyabinskogo gosudarstvennogo universiteta [Chelyabinsk State University Bulletin]. No. 3. Pp. 56-60. (In Russ.)

Sivceva S. I. (2013) Naselenie Yakutii v XX veke: nekotorye aspekty formirovaniya. In: Problemy istoricheskoj demografii Sibiri. Vyp. 3. [Problems of historical demography of Siberia. Vol. 3.]. Novosibirsk, In-t istorii SO RAN Publ. Pp.55-67. (In Russ.)

Surnina N. M. (2009) Etnoehkonomicheskaya paradigma v kontekste teorii dialoga civilizacij. Vestnik Tomskogo gosudarstvennogo universiteta [Tomsk State University Journal]. No. 4. Pp. 5-12. (In Russ.)

Ehtnodemograficheskie vzaimodejstviya narodov Sibiri. Istoriko-statisticheskie dokumenty. (2003) Novosibirsk, NGU Publ. 138 p. (In Russ.)

Yadrincev N. M. (2003) Sibir' kak koloniya v geograficheskom, ehtnograficheskom $\mathrm{i}$ istoricheskom otnoshenii. Novosibirsk, Institut istorii SO RAN Publ. 556 p. (In Russ.) 